\title{
Affecting and Inhibiting Factors for Exclusive Breastfeeding: Systematic Literature Review
}

\author{
Shinta Alifiana Rahmawati ${ }^{1 *}$, Fitria Siswi Utami ${ }^{2}$, Esitra Herfanda ${ }^{3}$ \\ 1,2,3) Magister of Midwifery, Universitas ‘Aisyiyah Yogyakarta, Indonesia \\ *shintaalifiana76@gmail.com
}

\begin{abstract}
Background: Breastfeeding is one important step for the health and development of infants early in life. An international perspective, breastfeeding is important to increase the chances of a baby's survival. Newborns who are exclusively breastfed have a lower risk of dying from diarrhea and respiratory disease, benefits for cognitive and motor activities, improve the general health of the baby. The aim of the study was to identify affecting and inhibiting factors for exclusive breastfeeding. This study used a Systematic Literature Review (SLR). Searching article from 2013 to 2018, from PubMed, Science Direct, and Proquest databases. Total of 1,115 articles reviewed, 6 articles met the inclusion criteria. Results: Exclusive breastfeeding is very closely related to the support of cultural beliefs, practices, and values as well as social and professional encouragement. Husbands who provide support or motivation for exclusive breastfeeding will certainly give happiness to mothers during breastfeeding. Family support is a supporting factor which in principle is an activity both emotional and psychological given to mothers in providing exclusive breastfeeding. Knowledge is very important in shaping one's actions, one of which is the adequate knowledge of the mother about the importance of exclusive breastfeeding. Support of health workers and the workplace has a positive impact on mothers in providing exclusive breastfeeding. Conclusion: Affecting factors for exclusive breastfeeding was associated with husband, family, health worker, workplace support, cultural traditions, and knowledge. Inhibiting factors for exclusive breastfeeding are internal and external factors.
\end{abstract}

Keywords: Exclusive breastfeeding, Family Support, Husband Support, Workplace.

\section{INTRODUCTION}

Breastfeeding is one of the important steps for a baby's health and development early in life. Besides containing calories and protein, breast milk provides the immune protection needed for babies in the first year of life. Newborns who are exclusively breastfed have a lower risk of death from diarrhea and respiratory disease, benefits of cognitive and motor activities, improve the general health of infants (1). Breastfeeding has short and long-term benefits on the health of babies and mothers. Mothers have a low risk of breast cancer, ovarian cancer, and hypertension. Babies given breast milk are at a lower risk of increased systolic blood pressure, obesity, gastrointestinal infections, and endogenous eczema. An international perspective, breastfeeding is important to increase the chances of children's survival. Breastfeeding also provides emotional bonds, security, and 
conditions that benefit children in terms of personal and psychosocial development (2).

According to the World Health Organization (WHO) exclusive breastfeeding, only infants who are given breast milk, except for drugs or vitamins, without water or tea. When babies receive food other than breast milk, drugs, or vitamins before reaching 180 days, it can be considered as the beginning of the termination or failure of exclusive breastfeeding (1). Exclusive breastfeeding is the best food and ideal for babies. WHO has reviewed more than 3,000 studies showing that breastfeeding for six months is the most optimal period time for exclusive breastfeeding. The World Health Organization recommends exclusive breastfeeding for the first six months after birth. After that, partial breastfeeding for baby plus other foods until the age of two years. Data from WHO in 2016 still shows the average rate of exclusive breastfeeding in the new world is around 38 percent (3).

There are many factors related to the experience and duration of breastfeeding mothers (4), one of which is assistance and support from others, especially husbands and families. The baby's father affects the mother's decision to breastfeed the baby and their support affects the experience and duration of mothers for breastfeeding (5). Studies are showing that grandmothers can affect the decision of breastfeeding mothers and the duration mothers for breastfeeding. In particular, they can be an important source of support, empathy, and approval (2). Many mothers who return to work choose to stop breastfeeding, because they do not have enough time, there is no place for breastfeeding, and there is no storage for breastfeeding. Most mothers stop breastfeeding a few weeks after returning to work (6).
Mothers need a safe, clean, and private place in or near their workplace to continue breastfeeding. Possible conditions in the workplace, such as paid maternity leave, part-time work arrangements, facilities for storing breast milk, and the absence of breaks for breastfeeding, can help mothers to continue to provide exclusive breastfeeding. Studies report many challenges faced by working mothers who intend to continue breastfeeding (2). It is important to understand what factors influence and inhibit exclusive breastfeeding to prevent infant morbidity and mortality. This research helps to provide knowledge about the importance of exclusive breastfeeding and support mothers give exclusive breastfeeding.

\section{LITERATURE REVIEW}

Our method is a Systematic Literature Review (SLR). SLR is a systematic way of collecting, critically evaluating, integrating, and presenting findings from across multiple research studies on a research question or topic of interest (7). Literature search strategy using the PEOS method and making research questions. The results of the identification of the search method then in Pubmed, Science Direct, Proquest obtained 1115 search results data. The researcher conducted screening including the results of the same search data type and had the same research title. After the screening stage, the eligibility stage is then carried out, namely the suitability of the search data with the inclusion criteria set by the researcher, including 1) studies on maternal affecting and inhibiting factors giving exclusive breastfeeding, 2) extracting affecting and inhibiting factors, 3) full text, period 2013 - 2018, international journal. The results of the study obtained a lot of results and 
conducted screening until eligibility to get journals that were in accordance with the criteria of the study. Based on the results of the synthesis, there were 6 journals that were in accordance with the study criteria and then there would be critical analysis to obtain the best evidence in extracting affecting and inhibiting factors for exclusive breastfeeding as the highest quality research.

Table 1. Framework PICO

\begin{tabular}{|c|c|c|}
\hline Criteria & Inclusion & Exclusion \\
\hline $\begin{array}{l}\text { Population/ } \\
\text { Problem }\end{array}$ & $\begin{array}{l}\text { 1. Mothers who have } \\
\text { babies over the age of } 6 \\
\text { months and provide } \\
\text { exclusive breastfeeding. } \\
\text { 2. Mothers who give birth } \\
\text { normally. } \\
\text { 3. Mothers who do not } \\
\text { have a serious illness. }\end{array}$ & $\begin{array}{l}\text { Mothers who } \\
\text { have } \\
\text { provided } \\
\text { additional } \\
\text { food to } \\
\text { infants under } \\
6 \text { months }\end{array}$ \\
\hline $\begin{array}{l}\text { Exposure/E } \\
\text { vent }\end{array}$ & $\begin{array}{l}\text { Affecting and inhibiting } \\
\text { factors for exclusive } \\
\text { breastfeeding }\end{array}$ & \\
\hline Outcomes & $\begin{array}{l}\text { Mother's decision to give } \\
\text { exclusive breastfeeding }\end{array}$ & \\
\hline $\begin{array}{l}\text { Study } \\
\text { Design }\end{array}$ & e study & \\
\hline \multicolumn{3}{|c|}{$\begin{array}{l}\text { The PICO format is commonly used in evidence- } \\
\text { based clinical practice and considered a widely } \\
\text { known strategy for framing a "foreground" research } \\
\text { question This format identifies four concepts: (1) the } \\
\text { Patient problem or Population, (2) the Intervention, } \\
\text { (3) the Comparison (if there is one), and (4) the } \\
\text { Outcome(s) (8). }\end{array}$} \\
\hline
\end{tabular}

The researcher conducts an assessment by looking at the factors that influence maternal decision making in providing exclusive breastfeeding using a qualitative, critical appraisal research design in the literature that has been eliminated from inclusion criteria. Study the quality of studies using Critical Appraisal Skills Program (CASP) 10 Question to help you make sense of a Qualitative Research. 
Figure 1. PRISMA flow diagram
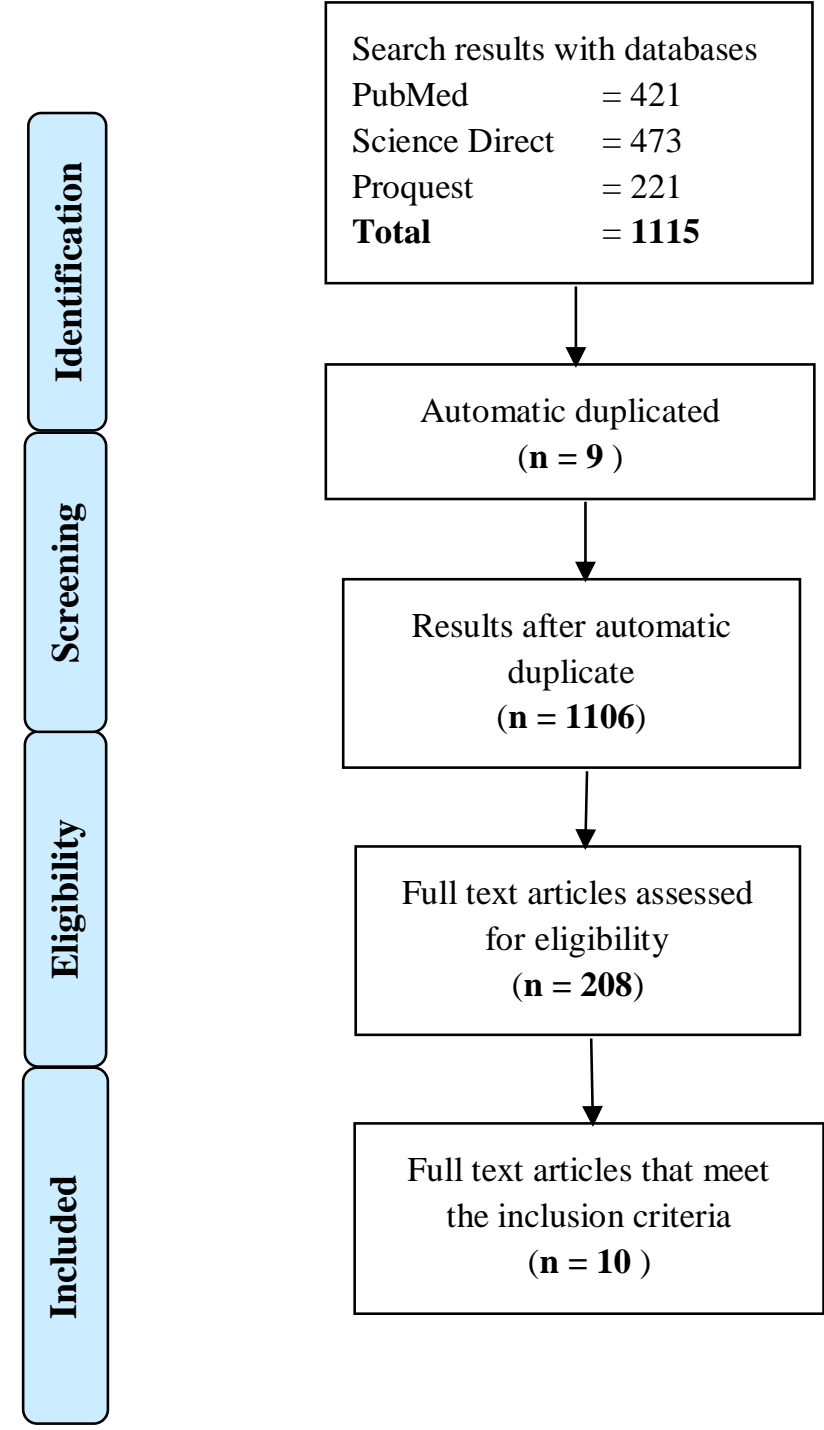

Results issued

Out of Topic

$=871$

Not English

$=8$

Review/Systematic Review

$=19$

Total

$=\mathbf{8 9 8}$

Full text articles issued because they do not meet the inclusion criteria (medical journal,

5 years of reference, human, full text, factors that affect exclusive breastfeeding) $(\mathbf{n}=198)$

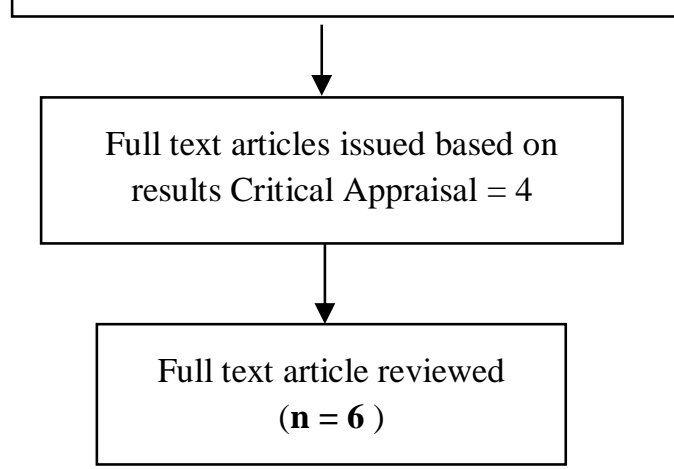




\section{Study characteristics}

Findings with systematic searches obtained articles published in 2013 - 2018, authors and sources of data taken came from American countries $(n=2)$, Sweden $(n=1)$, United Kingdom $(\mathrm{n}=1)$, Brazil $(\mathrm{n}=1)$, India $(\mathrm{n}=1)$. All articles use qualitative research methods. 4 articles taken in this systematic literature review are journals with Q1 and 2 quality articles with Q2 quality.

\section{Support husband}

The husband's support is affects the decision making of the mother in giving exclusive breastfeeding. Lawrence Green Theory suggests that the factor of husband's support can be said as one of the antecedent factors (enabling), which allows a motivation or aspiration to be carried out. The combination of education, knowledge, and support of a husband with a strong will from his wife in making choices on contraceptives that proved effective resulted in a unanimous decision for both partners in using contraception (9).

Husbands who provide support or motivation for exclusive breastfeeding will certainly provide happiness for mothers during breastfeeding. Mothers feel they get emotional support such as feeling calm, happy, feeling of belonging, affection given by her husband. In addition to emotional support the husband will also participate in taking care of the needs of the mother and baby, such as feeding the mother/wife while the mother is caring the baby, massaging the mother, always alert to changing the baby's diaper, accompanying the mother when she wakes up late at night to breastfeed the baby. The husband's support is very important and affects the mothers to give exclusive breastfeeding (9). Research by Evareny shows a significant relationship between family support and the role of fathers with exclusive breastfeeding behavior where the proportion of exclusive breastfeeding practices in the supportive father group is 2, 25 times higher than the group of unsupportive fathers (10).

Many participants identified that they could breastfeed exclusively since their husbands supported the decision of mothers to exclusively breastfeed. The husband is the main financial provider, so it allows the mother to stay close to the baby. Overall, participants described family members and friends, especially grandmothers, as the main role models and sources of support (2).

\section{Family support}

Family support is a supporting factor which in principle is an activity both emotional and psychological given to mothers in giving exclusive breastfeeding. A mother who has never received advice or counseling about breastfeeding from her family can influence attitudes or decisions when she has to breastfeed herself. On the positive side, mothers who get family support will choose to give exclusive breastfeeding to their babies because there is motivation and are taught how to breastfeed and the benefits of exclusive breastfeeding for babies (2).

Families always give motivation to mothers to give exclusive breastfeeding, and also many parents who already have experience on exclusive breastfeeding teach mothers how to breastfeed and the importance of exclusive breastfeeding for babies, and many families who replace babysitting when working. Mothers who do not get family support will be at risk of not giving exclusive breastfeeding to their 
babies because there is no knowledge and motivation that mothers should get from their families, so mothers choose to give formula milk to their babies. Mothers who get family support will choose to give exclusive breastfeeding to their babies because there is motivation and are taught how to breastfeed and the benefits of exclusive breastfeeding for babies.

Family support plays an important role in the success of breastfeeding mothers. The greater the support obtained to continue to provide exclusive breastfeeding, the greater the ability to continue to provide exclusive breastfeeding. While mothers who lack family support will be more easily influenced to switch to formula milk.

The more exclusive breastfeeding was given to respondents who received support from families $(75.7 \%)$ than those who did not get support from families (28.8\%). Statistical test results obtained pvalue $=0.001$, so it can be concluded that there is a significant relationship between family support and exclusive breastfeeding. The analysis also showed an OR value of 7.6, meaning that mothers who received family support had a 7.6 times greater chance of giving exclusive breastfeeding compared to mothers who did not get family support (11).

\section{Support health worker}

Bandura's theoretical agent construction was useful in the implementation of exclusive breastfeeding, but social practices such as family and the quality of relationships with family were needed for better correspondence by sharing experiences about breastfeeding. Support from health services and workplaces is very important for mothers to breastfeed exclusively (1).
The results of research by Rocha and Costa (12), are qualitative research entitled Early Interruption of Exclusive Breastfeeding: experience with mothers of children in child care consultations. The results of the study found that participants interviewed recognized the importance of breastfeeding. However, they are influenced by relatives and cultural problems, besides their lack of orientation, making them believe that "their milk is weak", which leads to initial weaning. Family influence, cultural problems, and lack of support have hurt harmed exclusive breastfeeding before the sixth month of life. Therefore, it is the responsibility of health professionals to invest in subjects related to breastfeeding promotion, protection, and support, which must be discussed comprehensively, with individuals, families, and all segments of society.

\section{Knowledge}

Knowledge affects for the mothers to give exclusive breastfeeding. The higher level of knowledge about exclusive breastfeeding, the higher success for exclusive breastfeeding. Mother's knowledge can be affected by information about exclusive breastfeeding. Knowledge is a very important thing in shaping one's actions, one of which is adequate knowledge of the mother about the importance of exclusive breastfeeding which makes the cause or problem in increasing exclusive breastfeeding. Counseling and guidance on the benefits of exclusive breastfeeding and the right way to give exclusive breastfeeding are very useful to increase knowledge about exclusive breastfeeding to mothers, so that mothers can understand exclusive breastfeeding and giving exclusive breastfeeding to their babies. Mothers can get knowledge about exclusive 
breastfeeding through health workers, families, or friends who know good knowledge about exclusive breastfeeding.

Knowledge is the result of human sensing or the result of knowing someone about an object through their senses which is influenced by the intensity of attention and perception of the object (13). According to Green's theory, knowledge is a predisposing factor for health behavior. It can be interpreted that to be able to do the right behavior requires good knowledge. Knowledge about exclusive breastfeeding is related to exclusive breastfeeding because the knowledge possessed by mothers affects the mindset that will form a positive attitude which is then applied in real behavior Green \& Ottoson (14). This study found that affect factors for exclusive breastfeeding are based on knowledge about the benefits of breastfeeding but also on the intuitive feeling of breastfeeding as something natural. Adaptation and acceptance of mothers during breastfeeding illustrates how participants hope that their children receive breast milk exclusively (5).

Based on research Septiani, et al (2017), exclusive breastfeeding is more in the group of mothers with good knowledge (72.8\%) than mothers with less knowledge (20.6\%). Statistical test results obtained pvalue $=0.001$, so it can be concluded that there is a significant relationship between knowledge and exclusive breastfeeding. The analysis also shows an OR value of 10.3 means that mothers with good knowledge have the opportunity to provide exclusive breastfeeding at 10.3 times greater than mothers who have sufficient knowledge. Similar to research conducted by Mekuria \& Edris (15) which also states that there is a significant relationship of knowledge with exclusive breastfeeding, where mothers with good knowledge are
2.6 times more likely to give exclusive breastfeeding. Research conducted by Sriningsih there is a significant relationship between knowledge about breastfeeding and exclusive breastfeeding behavior (16).

\section{Workplace}

The results showed that a lack of adherence to new laws, inadequate information on breastfeeding for mothers, and a lack of support from coworkers and supervisors emerged as a major obstacle to the success of breastfeeding in the workplace. Increase the support of breastfeeding in the workplace significantly, authentic collaboration is needed between motherchild and rural health institutions and businesses in creating a work environment that is tolerant of breastfeeding, flexible and forward-looking which, at least, complies with the law (17). Type of work and length of work affect the success of breastfeeding. Mothers who work in the administration or office have the opportunity to breastfeed their babies longer than mothers who work professionally. Mothers who work parttime also have the possibility of giving more time to breastfeeding than mothers who work full-time (17).

Based on research Septiani, et al, giving exclusive breastfeeding to respondents who received support from superiors was more $(65.9 \%)$ than those who did not get support (36.4\%) (11). Statistical test results obtained $\mathrm{p}$-value $=0.006$ $(<0.05)$, so it can be concluded that there is a relationship between superiors' support and exclusive breastfeeding. Exclusive breastfeeding is more on respondents who have the support of coworkers $(68.8 \%)$ than respondents who do not get support from coworkers $(41.1 \%)$. The statistical test results obtained $\mathrm{p}$-value $=0.008$, so it can be concluded that there is a significant 
relationship between coworkers' support and exclusive breastfeeding. The analysis also shows an OR value of 2.96, meaning that mothers who get coworkers' support have a 2.96 times greater chance of giving exclusive breastfeeding compared to mothers who do not get support from coworkers in exclusive breastfeeding.

Multivariate test results of mothers who received support did not increase the opportunity to provide exclusive breastfeeding where the $\mathrm{p}$-value $=0.173$. The success of working mothers in providing exclusive breastfeeding can be influenced by internal factors, namely the intention or commitment of mothers and external factors, namely factors that come from outside themselves, such as agency policies, superiors' support. Good support from superiors will not necessarily make the mother succeed in giving exclusive breastfeeding because there is a stronger factor namely how the commitment or intention of the mother, but the support and policy of agencies that do not support breastfeeding can be sure that there will be more working mothers who fail to give ASI (11).

Based on Rosyadi's research on the relationship between working hours of mothers with the success of exclusive breastfeeding with a p-value $=0.003$ (18) . Statistical test on workplace support variables obtained $p$-value $=0.044$, it was concluded that there is a relationship between workplace support and the success of exclusive breastfeeding. Inline Sholihah's research (19), $\mathrm{p}$-value $=0.011$ $<0.05$, which means there is a relationship between workplace support and exclusive breastfeeding for working mothers.

\section{Cultural traditions, guidance, support, values, and beliefs}

This study found that the affecting factors for exclusive breastfeeding were influenced by cultural traditions, guidance, support, values, and beliefs. Social and family support contributes to the decision of the mother to give exclusive breastfeeding. The practice of breastfeeding is very closely related to the support of cultural beliefs, practices, and social and professional values and encouragement. Participants reported that although the mother's decision to breastfeed was independent of herself, they still asked family members to give advice (2).

\section{Internal barriers inhibit factors giving exclusive breastfeeding}

A limited supply of breast milk and personal concerns of the mother is an obstacle for mothers in giving exclusive breastfeeding. Pain during breastfeeding and humility are common concerns that must be considered so that mothers continue to choose breastfeeding rather than formula milk (2). The research results of Bernie (20), found that the provision of formula milk among young mothers due to their perception of breastfeeding was embarrassing, deviated from social norms, and damaged social life.

Most mothers who fail to give exclusive breastfeeding because they consider their milk to be weak or insufficient to meet the baby's nutritional needs. The myth that breast milk does not meet the needs of babies because it is weak depends on the fact that the baby is breastfeeding and does not seem satisfied. It is important to highlight that breast milk contains all the nutrients that babies need and are easily digested (12). 
External barriers inhibit factors giving exclusive breastfeeding

The demands of work outside the home, there is no communication with the manager of the company where the mother works causes a lack of support for the mother to give breast milk to her baby. The company considers that breastfeeding is the mother's personal choice, so it does not give enough attention and support to mothers (21). In the practice of breastfeeding, family, experience, beliefs, traditions, sociocultural influences on early weaning or failure of exclusive breastfeeding in babies (12). Many parents of mothers still think that breast milk is not enough for babies, so they give formula milk so the baby does not cry and sleep well. The mother of the baby does not have a firm stance to give breast milk because of the lack of support from the family. This is what causes the failure of exclusive breastfeeding in babies. However, families also affect the failure of exclusive breastfeeding. Grandma was identified as important on some women, but there was concern that grandmothers sometimes lowered the intention of mothers to breastfeed exclusively. This is due to the knowledge of grandmothers who are still stiff and believe that breastfed babies are not enough and make babies fussy because of hunger, so grandmothers give food such as bananas or rice that has been crushed so that babies are full and sleep well (20).

According to Sutanto (22), the emergence of formula milk advertisements in various media is a major barrier to realizing exclusive breastfeeding programs. Advertising of formula milk is packaged as attractive as possible so that it is feared that it could damage the mother's perspective on exclusive breastfeeding. This can affect the understanding of mothers, where formula milk can meet all the nutritional needs of babies and children to be smart. If a milk formula is increasingly in demand by the mother, exclusive breastfeeding will decrease.

Based on research by Pernatun, et al (23), companies that do not provide a specific time for their employees to breastfeed or express milk at their workplaces, flexibility in working time, and duration of leave affect the success of exclusive breastfeeding. Besides providing space and tools three times better influence in supporting exclusive breastfeeding. According to Kartika's study (24), there is a relationship between the length of work and exclusive breastfeeding ( $\mathrm{p}$-value 0.002). No one who worked more than 8 hours gave exclusive breastfeeding. Like mothers who work during shift work hours, where the work system requires mothers to leave their babies longer. In addition, mothers who work shifts will easily experience fatigue. At work, it is required to do work, while at home the baby is waiting to be breastfed. This can affect the physical and psychological condition of the mother which will also affect the production of breast milk.

\section{CONCLUSION}

Affecting factors for exclusive breastfeeding were associated with husband support, family support, health worker support, knowledge, workplace and cultural traditions, guidance, support, values, and beliefs. Inhibiting factors for exclusive breastfeeding are internal and external factors. Increasing the knowledge of prospective mothers and families who accompany exclusive breastfeeding, including the definition of exclusive breastfeeding, the benefits for both mother and baby, how to breastfeed, good and 
correct breastfeeding techniques. There needs to be a collaboration with health workers to increase success in giving exclusive breastfeeding. Health workers need to monitor and provide counseling to nursing mothers so they can provide exclusive breastfeeding to their babies.

\section{ACKNOWLEDGMENT}

The authors wish to acknowledge Aisyiyah University, Yogyakarta, which has provided open-access journals in several databases. This research was not financially supported by any organization.

\section{CONFLICT OF INTEREST}

Authors state that have no conflict of interest, and no affiliation or connection to or with any entity or organization, which may raise a question of bias in discussion and conclusion of the manuscript.

\section{REFERENCE}

1. Omer-Salim A, Suri S, Dadhich JP, Faridi MMA, Olsson P. Theory and social practice of agency in combining breastfeeding and employment: A qualitative study among health workers in New Delhi, India. Women Birth. Netherlands; 2014 Dec;27(4):298-306.

2. Wambach K, Domian EW, Page-Goertz S, Wurtz H, Hoffman K. Exclusive Breastfeeding Experiences among Mexican American Women. J Hum Lact [Internet]. 2015/08/19. 2016 Feb;32(1):103-11. Available from: https://pubmed.ncbi.nlm.nih.gov/26289 059

3. Johnson $\mathrm{M}$, Whelan $\mathrm{B}$, Relton $\mathrm{C}$, Thomas K, Strong M, Scott E, et al. Valuing breastfeeding: a qualitative study of women's experiences of a financial incentive scheme for breastfeeding. BMC Pregnancy
Childbirth [Internet]. 2018;18(1):20. Available from: https://doi.org/10.1186/s12884-0171651-7

4. Thulier D, Mercer J. Variables associated with breastfeeding duration. $\mathrm{J}$ Obstet Gynecol neonatal Nurs JOGNN. United States; 2009;38(3):259-68.

5. Palmqvist $\mathrm{H}$, Zäther J, Larsson $\mathrm{M}$. Fathers\&\#x2019; and comothers\&\#x2019; voices about breastfeeding and equality \&\#x2013; A Swedish perspective. Women and Birth [Internet]. Elsevier; 2015 Sep 1;28(3):e63-9. Available from: https://doi.org/10.1016/j.wombi.2015.03 .005

6. Murtagh L, Moulton AD. Working mothers, breastfeeding, and the law. Am J Public Health. 2011 Feb;101(2):21723.

7. Pati D, Lorusso LN. How to Write a Systematic Review of the Literature. Heal Environ Res Des J. 2018;11(1):1530.

8. Cyrus J. Research Guides: How to Conduct a Literature Review (Health Sciences): Developing a Research Question [Internet]. 2020 [cited 2020 Mar 11]. Available from: https://guides.library.vcu.edu/healthsciences-lit-review/question

9. Rempel LA, Rempel JK, Moore KCJ. Relationships between types of father breastfeeding support and breastfeeding outcomes. Matern Child Nutr. 2017 Jul;13(3).

10. Evareny L, Hakimi M, Padmawati RS. Peran ayah dalam praktik menyusui. J Kebijak Kesehat Indones. 2010;26(4):187-95.

11. Septiani H, Budi A, Karbita. FaktorFaktor yang Berhubungan dengan Pemberian ASI Eksklusif oleh Ibu 
Menyusui yang Bekerja sebagai Tenaga

Kesehatan. Aisyah J Ilmu Kesehatan2. 2017;2(2):159-74.

12. Rocha, Maiara G, Costa E. Early Interruption of Exclusive Breastfeeding: Experience with Mothers of Children in Child-Care Consultations. Rev Bras Em Promocao Da Saude; Fortaleza. 2015;28(4):547-52.

13. Notoatmodjo S. Kesehatan Masyarakat, Ilmu dan Seni. Rineka Cipta; 2011.

14. Lawrence W. Green Judith M. Ottoson. A Framework for Planning and Evaluation: PRECEDE-PROCEED. Evolution and Application of the Model. In: 10Es Ans Journees De Sante Publique [Internet]. Montreal, Quebec; 2006. Available from: http://www.eldis.org/vfile/upload/1/doc ument/0803/id2188.pdf

15. Mekuria G, Edris M. Exclusive breastfeeding and associated factors among mothers in Debre Markos, Northwest Ethiopia: a cross-sectional study. Int Breastfeed J. 2015;10(1):1.

16. Sriningsih I. Faktor Demografi, Pengetahuan Ibu Tentang Air Susu Ibu dan Pemberian Asi Eksklusif. KEMAS J Kesehat Masy. 2011;6(2):100-6.

17. Novayelinda R. Telaah literatur: Pemberian ASI dan Ibu Bekerja. J Ners Indones. 2012;2(2):177-84.

18. Rosyadi D. Hubungan antara Pengetahuan Ibu Bekerja, Jam Kerja Ibu dan Dukungan Tempat Kerja dengan Keberhasilan Pemberian ASI Eksklusif Di Wilayah Kerja Puskesmas Banyudono I. Universitas Muhammadiyah Surakarta; 2016.

19. Sholihah N. Hubungan Dukungan Tempat Kerja dengan Pemberian ASI Eksklusif pada Ibu Bekerja di Wilayah Kerja Puskesmas Sewon II Kabupaten Bantul. Politeknik Kesehatan
Kementerian Kesehatan Yogyakarta; 2017.

20. Bernie K. The factors influencing young mothers' infant feeding decisions: the views of healthcare professionals and voluntary workers on the role of the baby's maternal grandmother. Breastfeed Med Off J Acad Breastfeed Med. United States; 2014 Apr;9(3):1615.

21. Majee W, Jefferson UT, Goodman LR, Olsberg JE. Four Years Later: Rural Mothers' and Employers' Perspectives on Breastfeeding Barriers Following the Passage of the Affordable Care Act. J Health Care Poor Underserved. United States; 2016;27(3):1110-25.

22. Sutanto M. Iklan Susu Formula Melampaui Batas Etika. 2015; Available from:

https://www.antaranews.com/berita/501 452/aimi-iklan-susu-formula-lampauibatas-etika

23. Pernatun C, Retna E, Retno E. Dukungan Tempat Kerja terhadap Perilaku Pemberian ASI Eksklusif. J Kebidanandan Keperawatan. 2014;10(1):27-36.

24. Kartika R. Hubungan Lamanya Jam Kerja Ibu Menyusui dengan Pemberian ASI pada Bayi Usia 0-6 Bulan di Desa Bangsri Kecamatan Bangsri Kabupaten Jepara. J Kesehat dan Budaya. 2015;8(2):26-32. 